\title{
DNA-DNA hybridization study of Bradyrhizobium strains
}

\author{
1 Laboratorium voor \\ Microbiologie, Faculteit \\ Wetenschappen, \\ Universiteit Gent, K. L. \\ Ledeganckstraat 35, \\ B-9000 Gent, Belgium \\ 2 Laboratoire des Symbioses \\ Tropicales et \\ Méditerranéennes (LSTM), \\ UMR 113 INRA/AGRO- \\ M/CIRAD/IRD, TA 10/J, \\ Campus International de \\ Baillarguet, 34398 \\ Montpellier Cedex 5, \\ France
}

\author{
Anne Willems, ${ }^{1}$ Florence Doignon-Bourcier, ${ }^{2}$ Johan Goris, ${ }^{1}$ \\ Renata Coopman, ${ }^{1}$ Philippe de Lajudie, ${ }^{2}$ Paul De Vos ${ }^{1}$ \\ and Monique Gillis ${ }^{1}$
}

Author for correspondence: Anne Willems. Tel: +32 9 2645103. Fax: + 3292645092. e-mail: anne.willems@rug.ac.be

\begin{abstract}
DNA-DNA hybridizations were performed between Bradyrhizobium strains, isolated mainly from Faidherbia albida and Aeschynomene species, as well as Bradyrhizobium reference strains. Results indicated that the genus Bradyrhizobium consists of at least 11 genospecies, I to XI. The genospecies formed four subgeneric groups that were more closely related to each other ( $>40 \%$ DNA hybridization) than to other genospecies (<40\% DNA hybridization): (i) genospecies I (Bradyrhizobium japonicum), III (Bradyrhizobium liaoningense), IV and V; (ii) genospecies VI and VIII; (iii) genospecies VII and IX; and (iv) genospecies II (Bradyrhizobium elkanii), $X$ and XI. Photosynthetic Aeschynomene isolates were found to belong to at least two distinct genospecies in one subgeneric group. DNA-DNA hybridization data are compared with data from amplified fragment length polymorphism analysis and 16S-23S rDNA spacer sequence analysis.
\end{abstract}

Keywords: Bradyrhizobium, DNA-DNA hybridizations, AFLP

\section{INTRODUCTION}

The genus Bradyrhizobium was created to accommodate slow-growing bacteria capable of nitrogen fixation and nodule formation on leguminous plants (Jordan, 1982). Currently, it contains three named species, Bradyrhizobium japonicum (type species), Bradyrhizobium elkanii and Bradyrhizobium liaoningense. Most of the strains that belong to these species were isolated or associated with nodules on Glycine spp. In addition to the species subdivision, a number of serogroups have been described among slow-growing soybean symbionts (Date \& Decker, 1965). Many other slow-growing rhizobia have been isolated from other legume hosts such as Arachis hypogaea (Urtz \& Elkan, 1996; Zhang et al., 1999), Lupinus (Barrera et al., 1997), Aeschynomene (Molouba et al., 1999) and others (Laguerre et al., 1997; Lafay \& Burdon, 1998; Vinuesa et al., 1998; Sterner \& Parker, 1999; Doignon-Bourcier et al., 1999). They are commonly referred to as Brady-

A table of detailed experimental data is presented in IJSEM Online (http://ijs.sgmjournals.org/cgi/content/full/51/4/1315/DC1).

Abbreviations: AFLP, amplified fragment length polymorphism; ARDRA, amplified $r D N A$ restriction analysis; $T_{\mathrm{OR}}$, optimal renaturation temperature. rhizobium sp. followed by the name of the legume host. Apart from the fact that they are mostly known to be distinct from the three named species, their taxonomic status and interrelationships are unresolved at present.

To find a fast, simple and reliable method for initial grouping of bradyrhizobia, various techniques have been assessed and used over several years. Previously, a large number of Bradyrhizobium strains from Faidherbia albida, Aeschynomene species and various small legumes from West Africa had been characterized using 16S rDNA sequence analysis, SDSPAGE of total cellular proteins (Dupuy et al., 1994; Doignon-Bourcier et al., 1999), 16S rDNA RFLP analysis (Molouba et al., 1999; Doignon-Bourcier et al., 1999) and amplified fragment length polymorphism (AFLP) analysis (Doignon-Bourcier et al., 2000; Willems et al., 2000). With each of these techniques, groupings were obtained that complemented each other and provided an insight into the relationships of these bacteria at different taxonomic levels. The genotypic methods were the most reproducible, but each had certain drawbacks. Because the 16S rDNA of bradyrhizobia shows little variation (Barrera et al., 1997), RFLP or sequence analysis of this molecule provided little discrimination in a clearly quite diverse group. AFLP analysis did provide 34 
groups (including named species), but was quite laborious to perform (Willems et al., 2000). In a further attempt to identify a fast initial grouping method, nine of the AFLP clusters were selected and the sequences of the 16S-23S rDNA spacers were determined (Willems et al., 2001). Analysis of these data revealed groups similar to the AFLP clusters, but also provided additional information on relationships between the different groups. However, because DNA-DNA hybridization levels are still considered to be an important criterion for species delineation (Stackebrandt \& Goebel, 1994), the true taxonomic significance of these groups and their possible relationships had to be evaluated using DNA-DNA hybridization. These experiments proved that AFLP clusters, as well as ITS groupings, can be correlated with genomic species (Willems et al., 2001). In this paper, more extensive DNA-DNA hybridization data among bradyrhizobia representing 34 of the previously identified AFLP clusters are presented. Representatives of three additional AFLP clusters comprising Bradyrhizobium strains from small legumes (DoignonBourcier et al., 2000) were also included. The possible taxonomic implications of the findings are discussed.

\section{METHODS}

Strains used. The strains studied are listed in Table 1. They were grown on yeast mannitol agar (YMA), pH 6.8, comprising $\left(\mathrm{g}^{-1}\right)$ : mannitol, 10 ; sodium glutamate, 0.5 ; $\mathrm{K}_{2} \mathrm{HPO}_{4}, 0.5 ; \mathrm{MgSO}_{4} .7 \mathrm{H}_{2} \mathrm{O}, 0 \cdot 2 ; \mathrm{NaCl}, 0.05 ; \mathrm{CaCl}_{2}, 0.04$; $\mathrm{FeCl}_{3}, 0 \cdot 004$; yeast extract, 1 ; agar, 20. Purity was verified by repeated streaking and microscopic examination of living and Gram-stained cells.

DNA preparation. For DNA preparation, $800 \mathrm{ml}$ liquid shake cultures in yeast mannitol broth were used. Purity of the cultures was verified by microscopic examination and by streaking a sample onto YMA. Cells were harvested by centrifugation and DNA was prepared by the method of Marmur (1961) with the following small modifications. Before lysis, cells were suspended in at least $100-150 \mathrm{ml}$ saline/EDTA per $2 \mathrm{~g}$ cells and proteinase $\mathrm{K}$ (Merck) was added to a concentration of $8 \mu \mathrm{g} 100 \mathrm{ml}^{-1}$. After lysis, to separate nucleic acids from proteins, $\mathrm{NaCl}$ was used instead of sodium perchlorate used in the standard procedure.

Many strains produced exopolysaccharides. These were usually eliminated by extra washing of the cells. However, a few of the strains produced such large amounts of exopolysaccharides that cell harvesting by centrifugation was seriously hampered. In those cases, a mild alkaline hydrolysis step, introduced before cell lysis, significantly improved the cell yield. The first centrifugation of the culture typically yielded only a very small cell pellet, a large cloud-like and lumpy interphase of cells caught up in polysaccharides and a smaller layer of clear culture liquid. The clear culture liquid was discarded and the small cell pellet was separated from the cloudy interphase and reserved on ice. The volume of the interphase was estimated and it was transferred to a separate Erlenmeyer flask, mixed gently with an equal volume of $0 \cdot 1 \mathrm{M} \mathrm{NaOH}$ and incubated at $60{ }^{\circ} \mathrm{C}$, while mixing gently from time to time. After about $5 \mathrm{~min}$, most of the small lumps had disappeared. The mixture was incubated for a total of $10 \mathrm{~min}$ and sometimes looked quite viscous by the end of this time. Cells were then harvested by centrifugation for $15 \mathrm{~min}$ at $8000 \mathrm{~g}$. A large clean pellet was obtained and the supernatant, which was still very viscous and with an unpleasant smell, was discarded. The cell pellet was washed with sterile TEK buffer, which contained $\left(1^{-1}\right) 4.85 \mathrm{~g}$ Tris(hydroxymethyl)aminomethane and $0.75 \mathrm{~g}$ Titriplex III (Merck) (pH 8), together with the first small cell pellet and was used for DNA preparation as described above.

DNA-DNA hybridization. Because large quantities of highmolecular-mass DNA are quite difficult to obtain from bradyrhizobia, a microplate method was used in which unlabelled DNA, non-covalently bound to a microplate, was hybridized with biotinylated probe DNA (Ezaki et al., 1989). This technique was previously shown to give results comparable to those obtained with the initial renaturation rate method of De Ley et al. (1970) (Goris et al., 1998). Major advantages of this method are that it is fast, requires relatively little DNA and can be automated. Fixed DNAs can be stored, but for efficient non-covalent fixation, pure high-molecular-mass DNA preparations are required. The quality and purity of the DNAs was verified by agarose gel electrophoresis and by spectrophotometric determination of the values $\mathrm{OD}_{260} / \mathrm{OD}_{280}$ and $\mathrm{OD}_{234} / \mathrm{OD}_{260}$, which were at least 1.8 and about 0.5 , respectively.

The protocol followed was slightly modified from Ezaki et al. (1989). Briefly, DNA was non-covalently adsorbed to polystyrene microplates (black MaxiSorp, FluoroNunc; Nunc) by incubating $100 \mu \mathrm{l}$ portions of a denatured DNA solution $\left(10 \mathrm{ng}\right.$ DNA $\left.\mu l^{-1}\right)$ in $\mathrm{PBS} / \mathrm{MgCl}_{2}\left(8 \mathrm{mM} \mathrm{NaH}{ }_{2} \mathrm{PO}_{4}\right.$, $1.5 \mathrm{mM} \mathrm{KH}_{2} \mathrm{PO}_{4}, \mathrm{pH} 7 \cdot 2,137 \mathrm{mM} \mathrm{NaCl}, 2.7 \mathrm{mM} \mathrm{KCl}$, $0 \cdot 1 \mathrm{M} \mathrm{MgCl}_{2}$ ) per well at $30{ }^{\circ} \mathrm{C}$ for $4 \mathrm{~h}$ in a ShelLab model 1004 hybridization oven (Sheldon Manufacturing). Before incubation, plates were sealed with self-adhesive vinyl tape (Nunc). Plates were then washed once with $300 \mu \mathrm{l}$ PBS per well using a Wellwash Ascent microplate washer (Labsystems), dried at $45^{\circ} \mathrm{C}$ for $15 \mathrm{~min}$ and stored in a desiccator at room temperature. Probe DNA was labelled by mixing $10 \mu \mathrm{l}$ DNA solution $\left(0.5 \mu \mathrm{g} \mathrm{l}^{-1}\right)$ in $0 \cdot 1 \times \operatorname{SSC}(1 \times$ $\mathrm{SSC}$ is $0.15 \mathrm{M} \mathrm{NaCl}$ plus $0.015 \mathrm{M}$ sodium citrate, $\mathrm{pH}$ $7 \cdot 0 \pm 0 \cdot 2)$ plus $10 \mu$ l photobiotin solution (Sigma) $\left(0 \cdot 5 \mu \mathrm{g} \mu \mathrm{l}^{-1}\right.$ in water) in a $1.5 \mathrm{ml}$ Eppendorf tube and illuminating the mixture for 30 min under a $400 \mathrm{~W}$ mercury vapour lamp while the open tube was kept upright in a cooling block on ice. The labelled probe DNA was diluted by adding $185 \mu \mathrm{l}$ $0 \cdot 1 \mathrm{M}$ Tris $/ \mathrm{HCl}(\mathrm{pH} 9 \cdot 0)$ and the remaining free photobiotin was removed by extracting twice with $200 \mu \mathrm{l} 1$-butanol saturated with $0 \cdot 1 \mathrm{M}$ Tris $/ \mathrm{HCl}(\mathrm{pH} 9 \cdot 0)$. The probe DNA was then sonicated for $30 \mathrm{~s}$ at $10 \mathrm{~W}$ (Misonix Microson ultrasonic cell disruptor), denatured at $100^{\circ} \mathrm{C}$ for $10 \mathrm{~min}$ and immediately cooled on ice. A pre-hybridization step was performed by adding $200 \mu \mathrm{l}$ pre-hybridization solution per well $[2 \times \mathrm{SSC}, 5 \times$ Denhardt's solution, $50 \%(\mathrm{v} / \mathrm{v})$ formamide, $100 \mu \mathrm{g}$ denatured salmon sperm DNA ml $\mathrm{m}^{-1}$, sealing the microplate with vinyl tape and incubating for $30 \mathrm{~min}$ at $50{ }^{\circ} \mathrm{C}$ in the hybridization oven. For the actual hybridization, the pre-hybridization solution was removed and $100 \mu \mathrm{l}$ hybridization solution [pre-hybridization solution plus $2.5 \%(\mathrm{w} / \mathrm{v})$ dextran sulfate and $1 \mu \mathrm{g}$ probe DNA $\mathrm{ml}^{-1}$ ] was added per well. The microplate was sealed with vinyl tape and incubated for $3 \mathrm{~h}$ at $50^{\circ} \mathrm{C}$. This temperature represents stringent conditions for Bradyrhizobium, for which the optimal renaturation temperature $\left(T_{\mathrm{OR}}\right)$ in the presence of $50 \%$ formamide is $42-44{ }^{\circ} \mathrm{C}$. $T_{\mathrm{OR}}\left({ }^{\circ} \mathrm{C}\right)$ is calculated as $[(0.51 \times \mathrm{G}+\mathrm{C}$ content $)+47]-36$ (Gillis et al., 1970), where $36^{\circ} \mathrm{C}$ is the correction for the presence of $50 \%$ formamide (McConaughy et al., 1969). The microplate was then washed three times with $300 \mu 11 \times$ SSC per well using 
Table 1. Strains used in this study

\begin{tabular}{|c|c|c|c|c|c|}
\hline Species & Collection number(s)* & Host plant $\dagger$ & Genospecies & AFLP $\$$ & ARDRA $\S$ \\
\hline Bradyrhizobium japonicum & LMG 4252, Bonnier 3.1 & Glycine $\max$ & I & 15 & B \\
\hline Bradyrhizobium japonicum & LMG $6138^{\mathrm{T}}$, NZP $5549^{\mathrm{T}}$ & Glycine $\max$ & I & 15 & B \\
\hline Bradyrhizobium japonicum & USDA 110 & Glycine $\max$ & I & 12 & $\mathrm{E}$ \\
\hline Bradyrhizobium elkanii & LMG $6134^{\mathrm{T}}$, NZP $5531^{\mathrm{T}}$ & Glycine $\max$ & II & 32 & $\mathrm{C}$ \\
\hline Bradyrhizobium elkanii & LMG 6135, NZP 5532 & Glycine $\max$ & II & 32 & $\mathrm{C}$ \\
\hline Bradyrhizobium liaoningense & LMG $18230^{\mathrm{T}}, 2281^{\mathrm{T}}$ & Glycine $\max$ & III & 16 & B \\
\hline Bradyrhizobium liaoningense & LMG 18231, 2062 & Glycine soja & III & 16 & $\mathrm{~B}$ \\
\hline Bradyrhizobium sp. & LMG 10664, ORS 101 & Faidherbia albida, Senegal & IV & 20 & \\
\hline Bradyrhizobium sp. & LMG 10702, ORS 146 & Faidherbia albida, Diokoul, Senegal, $14 \mathrm{~m}$ & IV & 20 & \\
\hline Bradyrhizobium sp. & LMG 10726, ORS 187 & Faidherbia albida, North Senegal & IV & 20 & B \\
\hline Bradyrhizobium sp. & LMG 10727, ORS 188, LMG 15185 & Faidherbia albida, North Senegal & IV & 20 & \\
\hline Bradyrhizobium sp. & LMG 15269, ORS 935 & Rynchosia minima, Gueye Kadar, Ferlo, Senegal & IV & 20 & E \\
\hline Bradyrhizobium sp. & LMG 11947 , ORS 152 & Faidherbia albida, Djinaki, Senegal, $1.5 \mathrm{~m}$ & $\mathrm{~V}$ & 22 & \\
\hline Bradyrhizobium sp. & LMG 11950 , ORS 155 & Faidherbia albida, Djinaki, Senegal, 3 m & $\mathrm{V}$ & 22 & \\
\hline Bradyrhizobium sp. & LMG 11953, ORS 158 & Faidherbia albida, Djinaki, Senegal, $5 \mathrm{~m}$ & $\mathrm{~V}$ & 22 & \\
\hline Bradyrhizobium sp. & LMG 11955, ORS 176 & Faidherbia albida, Kabrousse, Senegal, $0.1 \mathrm{~m}$ & $\mathrm{~V}$ & 23 & \\
\hline Bradyrhizobium sp. & LMG 11807, ORS 376, LMG 15389 & Aeschynomene indica $(\mathrm{S}, \mathrm{f})$ & VI & 2 & \\
\hline Bradyrhizobium sp. & LMG 12205, ORS 392, LMG 11812 & Aeschynomene indica $(\mathrm{S}, \mathrm{f})$ & VI & 3 & A \\
\hline Bradyrhizobium sp. & LMG 15407, ORS 393, LMG 11811 & Aeschynomene indica $(\mathrm{S}, \mathrm{f})$ & VI & 3 & A \\
\hline Bradyrhizobium sp. & LMG 12198, ORS 344 & Aeschynomene indica $(\mathrm{S}, \mathrm{f})$ & VI & 5 & \\
\hline Bradyrhizobium sp. & LMG 8293, ORS 308, LMG 15401 & Aeschynomene afraspera $(\mathrm{R}, \mathrm{f})$ & VI & 6 & \\
\hline Bradyrhizobium sp. & LMG 8295, ORS 324 & Aeschynomene afraspera $(\mathrm{R}, \mathrm{f})$ & VI & 6 & A \\
\hline Bradyrhizobium sp. & LMG 10300, ORS 351 & Aeschynomene afraspera $(\mathrm{S}, \mathrm{f})$ & VI & 6 & \\
\hline Bradyrhizobium sp. & LMG 15400, ORS 300, LMG 12197 & Aeschynomene indica $(\mathrm{S}, \mathrm{f})$ & VI & 6 & A \\
\hline Bradyrhizobium sp. & LMG 15391, ORS 385 & Aeschynomene indica $(\mathrm{S}, \mathrm{f})$ & VI & 7 & \\
\hline Bradyrhizobium sp. & LMG 11800 , ORS 336 & Aeschynomene indica $(\mathrm{S})$ & VI & 8 & \\
\hline Bradyrhizobium sp. & LMG 12196, ORS 298 & Aeschynomene sensitiva $(\mathrm{S}, \mathrm{f})$ & VI & 9 & A \\
\hline Bradyrhizobium sp. & LMG 15388, ORS 375 & Aeschynomene indica $(\mathrm{S}, \mathrm{f})$ & VI & 10 & \\
\hline Bradyrhizobium sp. & LMG 12186, ORS 277 & Aeschynomene sensitiva $(\mathrm{S}, \mathrm{f})$ & VI & 13 & A \\
\hline Bradyrhizobium sp. & LMG 12188, ORS 279 & Aeschynomene sensitiva $(\mathrm{S}, \mathrm{f})$ & VI & 13 & A \\
\hline Bradyrhizobium sp. & LMG 10667, ORS 111 & Faidherbia albida, Louga, Senegal, $0.5 \mathrm{~m}$ & VII & 33 & \\
\hline Bradyrhizobium sp. & LMG 10668, ORS 112 & Faidherbia albida, Louga, Senegal, $0.5 \mathrm{~m}$ & VII & 33 & \\
\hline Bradyrhizobium sp. & LMG 10676, ORS 120 & Faidherbia albida, Louga, Senegal, $2.5 \mathrm{~m}$ & VII & 33 & \\
\hline Bradyrhizobium sp. & LMG 10717 , ORS 174 & Faidherbia albida, Casamance, Senegal & VII & 33 & $\mathrm{C}$ \\
\hline Bradyrhizobium sp. & LMG 15181, ORS 117, LMG 10673 & Faidherbia albida, Louga, Senegal, $0.5 \mathrm{~m}$ & VII & 33 & \\
\hline Bradyrhizobium sp. & LMG 8070 , ORS 309 & Aeschynomene uniflora $(\mathrm{C})$ & VII & 34 & $\mathrm{C}$ \\
\hline Bradyrhizobium sp. & LMG 10303 , ORS 358 & Aeschynomene nilotica & VII & 34 & $\mathrm{C}$ \\
\hline Bradyrhizobium sp. & LMG 15179, ORS 89 & Tephrosia purpurea, Bourel, Ferlo, Senegal & VII & 34 & $\mathrm{C}$ \\
\hline Bradyrhizobium sp. & LMG 15176, ORS 86 & Tephrosia purpurea, Bourel, Ferlo, Senegal & VII & 40 & $\mathrm{C}$ \\
\hline Bradyrhizobium sp. & LMG 15178 , ORS 88 & Tephrosia purpurea, Bourel, Ferlo, Senegal & VII & 40 & $\mathrm{C}$ \\
\hline Bradyrhizobium sp. & LMG 8300, ORS 306, LMG 11797 & Aeschynomene indica $(\mathrm{S}, \mathrm{f})$ & VIII & 28 & A \\
\hline Bradyrhizobium sp. & LMG 10677, ORS 121 & Faidherbia albida, Louga, Senegal, $2.5 \mathrm{~m}$ & IX & 29 & $\mathrm{C}$ \\
\hline Bradyrhizobium sp. & LMG 10691, ORS 135 & Faidherbia albida, Louga, Senegal, $32 \mathrm{~m}$ & IX & 30 & \\
\hline Bradyrhizobium sp. & LMG 10705, ORS 162 & Faidherbia albida, Casamance, Senegal & $\mathrm{x}$ & 31 & $\mathrm{C}$ \\
\hline Bradyrhizobium sp. & LMG 10706, ORS 163 & Faidherbia albida, Casamance, Senegal & $\mathrm{X}$ & 31 & \\
\hline Bradyrhizobium sp. & LMG 11951, ORS 156 & Faidherbia albida, Djinaki, Senegal, $4 \mathrm{~m}$ & $\mathrm{XI}$ & 19 & \\
\hline Bradyrhizobium sp. & LMG 15245 , ORS 1814 & Crotalaria hyssopifolia, Casamance, Senegal & XI & 19 & $\mathrm{C}$ \\
\hline Bradyrhizobium sp. & LMG 15253, ORS 1824 & Indigofera hirsuta, Wouring, Niokolokoba, Senegal & XI & 19 & $\mathrm{C}$ \\
\hline Bradyrhizobium sp. & LMG 11815, ORS 386 & Aeschynomene indica $(\mathrm{S}, \mathrm{f})$ & & 11 & A \\
\hline Bradyrhizobium sp. & LMG 12200 , ORS 348 & Aeschynomene sp. & & 4 & $\mathrm{D}$ \\
\hline Bradyrhizobium sp. & LMG 10306, ORS 366 & Aeschynomene sp. & & 14 & \\
\hline Bradyrhizobium sp. & LMG 10720, ORS 181 & Faidherbia albida, North Senegal & & 17 & \\
\hline Bradyrhizobium sp. & LMG 10716, ORS 173 & Faidherbia albida, Casamance, Senegal & & 18 & \\
\hline Bradyrhizobium sp. & LMG 8290, ORS 301 & Aeschynomene americana $(\mathrm{R})$ & & 21 & B \\
\hline Bradyrhizobium sp. & LMG 10666, ORS 110 & Faidherbia albida, Louga, Senegal, $0.5 \mathrm{~m}$ & & 24 & B \\
\hline Bradyrhizobium sp. & LMG 10698, ORS 142 & Faidherbia albida, Diokoul, Senegal, $2.5 \mathrm{~m}$ & & 25 & \\
\hline Bradyrhizobium sp. & LMG 15422, ORS 379 & Aeschynomene elaphroxylon $(\mathrm{C})$ & & 27 & \\
\hline Bradyrhizobium sp. & LMG 15249, ORS 1819 & Crotalaria retusa, Kabrousse, Senegal & & 38 & $\mathrm{~F}$ \\
\hline Bradyrhizobium sp. & LMG 15165, ORS 29 & Indigofera tinctoria, Mbour, Senegal & & 43 & B \\
\hline Bradyrhizobium sp. & LMG 11801 , ORS 343 & Aeschynomene schimperi $(\mathrm{R})$ & & Sep & \\
\hline
\end{tabular}

* LMG number followed by the number as originally received; a second LMG number is given for strains received twice. LMG, BCCM/LMG Bacteria Collection, Laboratorium voor Microbiologie Gent, Universiteit Gent, Belgium; NZP, Culture Collection of the Department for Scientific and Industrial Research, Biochemistry Division, Palmerston North, New Zealand; ORS, Culture Collection of the Institut de Recherche pour le Développement, Montpellier, France; USDA, US Department of Agriculture, Beltsville, MD, USA.

$\dagger$ For Aeschynomene isolates, the location of the nodule is specified where known: (R), root nodule; (S), stem nodule; (C), collar (submerged lower part of the stem) nodule; (f), photosynthetic strain (Molouba et al., 1999). For Faidherbia albida isolates, the geographical location and depth of sampling are included where known.

\$AFLP grouping from Willems et al. (2000) and Doignon-Bourcier et al. (2000).

$\S$ ARDRA grouping from Molouba et al. (1999) and Doignon-Bourcier et al. (1999). 
the microplate washer. For the enzymic development, $100 \mu \mathrm{l}$ streptavidin- $\beta$-D-galactosidase (GibcoBRL) solution was added per well $\left(0.5 \mathrm{U} \mathrm{ml}^{-1}\right.$ in PBS plus $0.5 \%$ BSA) and the microplate was covered with a pre-heated empty microplate and incubated for $10 \mathrm{~min}$ at $37^{\circ} \mathrm{C}$. Subsequently, the plate was washed three times with $300 \mu 11 \times$ SSC per well using the microplate washer. Finally, the substrate for $\beta$-Dgalactosidase, 4-methylumbelliferyl- $\beta$-D-galactopyranoside (Sigma), was added ( $100 \mu \mathrm{l}$ per well, $0 \cdot 1 \mathrm{mg} \mathrm{ml}^{-1}$ in PBS plus $1 \mathrm{mM} \mathrm{MgCl}$ ) and the plate was incubated at $37^{\circ} \mathrm{C}$. The reaction product, 4-methylumbelliferone (excitation max. $360 \mathrm{~nm}$, emission max. $465 \mathrm{~nm}$ ), was quantified using an HTS 7000 BioAssay Reader (Perkin Elmer) at times 0, 15, 30 and 45 min and data were immediately transferred to a PC. Reassociation values were calculated using the fluorescence values at $30 \mathrm{~min}$ and the homologous reaction is regarded as representing $100 \%$ reassociation.

For all hybridizations, four duplicate wells were used and hybridization values were calculated as a mean of these four experiments, with aberrant values being eliminated from further calculations. As an internal control, reciprocal hybridizations (different hybridizations using the same DNAs $\mathrm{A}$ and $\mathrm{B}$, but once with $\mathrm{A}$ as fixed DNA and once with $\mathrm{B}$ as fixed DNA) were nearly always carried out and values deviating by more than $20 \%$ were regarded as suspect and omitted. The reproducibility of the technique was good, with a mean standard deviation of $\pm 7 \%$.

\section{RESULTS AND DISCUSSION}

\section{Genospecies of Bradyrhizobium}

Previously reported DNA-DNA hybridizations between 9 of 34 AFLP clusters (clusters 3, 6, 12, 15, $16,20,22,32$ and 33) had demonstrated seven genospecies (I to VII) among Bradyrhizobium strains (Willems et al., 2001). It was also shown that, within an AFLP cluster, high DNA-DNA hybridization levels are found, so that one or a few strains can be used to represent an AFLP cluster. In the present study, DNA-DNA hybridizations were extended by including one or more representative strains of 32 of the 34 AFLP clusters (Willems et al., 2000). Strains from AFLP cluster 1 and 26 repeatedly failed to give sufficiently good quality DNA and were therefore not included. Strains from three additional AFLP groups that comprise strains from small legumes were also included (Table 1; AFLP clusters 38, 40 and 43). These are part of a larger AFLP study of the diversity of small legume isolates reported separately (DoignonBourcier et al., 2000).

A table of detailed experimental data on DNA-DNA hybridization is presented in IJSEM Online (http:// ijs.sgmjournals.org / cgi/content / full / 51 / 4 / 1315/ DC1). The findings confirm the previously described genospecies I to VII. Genospecies V, VI and VII were enlarged and a further four genospecies (VIII to XI) were revealed by using a criterion of at least $60 \%$ hybridization within a genospecies. At this level, Bradyrhizobium japonicum groups I and Ia were grouped, but were distinct from Bradyrhizobium liaoningense. To provide a comprehensive overview of all data available, a selection of previously published results is also included. Thus, 11 Bradyrhizobium genospecies can now be recognized by DNA-DNA hybridizations. They formed four subgeneric groups of genospecies more closely related to each other (40-60\% hybridization) than to other genospecies (less than $40 \%$ hybridization). These relationships are presented in a schematic overview in Fig. 1.

Genospecies I represented Bradyrhizobium japonicum and included both DNA group I and Ia of Hollis et al. (1981). Because strain USDA 110 was our only representative of group Ia, it cannot be concluded from our data that group Ia is recognizable as a separate subspecies as suggested by Hollis et al. (1981). However, from both AFLP and ITS sequence analysis (Willems et al., 2000, 2001), this seems very likely. Because historically Bradyrhizobium elkanii was the second species described and because it was referred to as group II in the work of Hollis et al. (1981), the genospecies II designation for this species has been reserved. It will be discussed below with other related genospecies. Genospecies III was Bradyrhizobium liaoningense, which was found to be highly related to genospecies I (Bradyrhizobium japonicum), IV and V, with between-genospecies hybridization values of 31$61 \%$ (mean $48 \pm 7 \%$ ). Genospecies IV comprised strains of AFLP cluster 20, isolated mostly from the tree F. albida in West Africa. However, it also included a strain from Rynchosia minima, a small herbaceous legume, and a strain from Glycine max which was not included in DNA-DNA hybridizations, but does belong to genospecies IV according to AFLP data (Willems et al., 2000) and ITS sequences (Willems et al., 2001). The latter strain (LMG $8321=$ USDA 135) is therefore probably not Bradyrhizobium japonicum, as is suggested by its origin. Genospecies V comprised strains of AFLP clusters 22 and 23, all isolates from $F$. albida. The four genospecies I, III, IV and V represented a group of closely related organisms, together with three other strains representing a further three AFLP clusters. Strains LMG 10720 (AFLP cluster 17), LMG 10716 (AFLP cluster 18) and LMG 8290 (AFLP cluster 21) had DNA-DNA hybridization values of $37-65 \%$ with each other and $25-66 \%$ with genospecies I, III, IV and V. They could not unequivocally be assigned to any of these genospecies and may be intermediate strains or representatives of additional genospecies. This should be investigated by further DNA-DNA hybridizations including additional strains of these AFLP clusters.

Genospecies VI included strains representing AFLP clusters 2, 3, 5, 6, 7, 8, 9, 10 and 13, all isolated from Aeschynomene species and most of them photosynthetic. DNA-DNA hybridization values in this group showed a large variation $(43-100 \%$; mean $64 \pm 14 \%)$ and this variation was repeatedly observed among strains of the same AFLP cluster, as well as among strains from different AFLP clusters. In this genospecies, at least two highly related infraspecific groups may be recognized: strains of AFLP clusters 6-9 and strains of AFLP clusters 2 and 3 may represent 


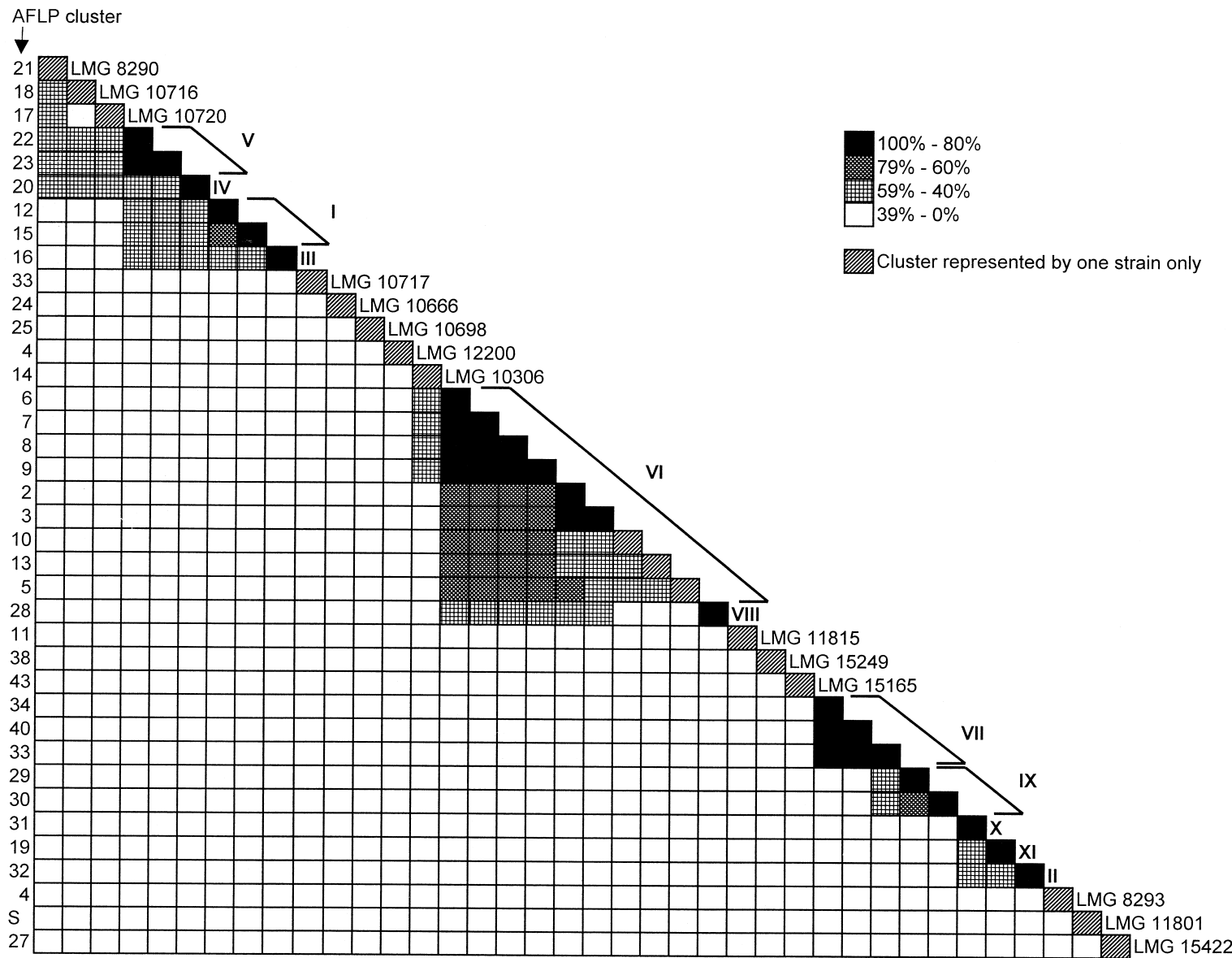

Fig. 1. Summary of the DNA-DNA hybridization data. Rows represent the different AFLP groups of strains that were included. Roman numerals refer to the different genospecies. For clusters represented by just one strain that have not yet been assigned to a particular genospecies, the strain studied is listed.

two highly related groups, comparable with DNA groups I (AFLP cluster 15) and Ia (AFLP cluster 12) in genospecies I (Bradyrhizobium japonicum). They showed DNA-DNA hybridizations with each other of $46-76 \%$ (mean $59 \pm 10 \%$; see table in IJSEM Online). In an alternative interpretation of the data, these two groups could be regarded as separate, highly related species (comparable to Bradyrhizobium japonicum and Bradyrhizobium liaoningense). However, because the hybridization values between the groups can reach $76 \%$, they can, for now, be regarded as subspecific groups on their way to becoming closely related genospecies. Additional data from other techniques are needed to elucidate this relationship more precisely. Strains LMG 15388 (AFLP cluster 10), LMG 12186 and LMG 12188 (AFLP cluster 13), and LMG 12198 (AFLP cluster 5) could not unequivocally be assigned to one of these subspecific groups in genospecies VI, but they are closely related and may represent intermediate strains or additional subspecies. Genospecies VIII consisted of the AFLP cluster 28 strains: two photosynthetic Aeschynomene isolates LMG 8300 (= LMG 11797) and LMG 11795 (= BTAi1). The latter strain was not included in DNA-DNA hybridizations but belonged to genospecies VIII on the basis of AFLP (Willems et al., 2000) and 16S-23S rDNA spacer RFLP analysis (Doignon-Bourcier et $a l ., 2000$ ). With hybridization values of $24-54 \%$ (mean $40 \pm 8 \%$ ) with genospecies VI versus values of less than $34 \%$ with the other genospecies (mean $18 \pm 6 \%$; see table in IJSEM Online), genospecies VIII showed a somewhat closer relationship towards genospecies VI, which also contained photosynthetic Aeschynomene isolates.

Genospecies VII comprised members of AFLP clusters 33, 34 and 40 isolated from F. albida, Aeschynomene species and several small legume species and thus appears to be not particularly host specific. The Aeschynomene isolates in this genospecies were not photosynthetic. Genospecies IX consisted of members of AFLP clusters 29 and 30, isolated from $F$. albida. It was most closely related to genospecies VII (hybridization values $46-55 \%$; see table in IJSEM Online).

Genospecies X and XI comprised members of AFLP clusters 31 (strains isolated from F. albida) and 19 (strains isolated from $F$. albida and several small legumes). They were closely related to each other and 
to genospecies II (Bradyrhizobium elkanii), with hybridization values between genospecies of $37-58 \%$ (mean $47 \pm 8 \%$ ). Strain LMG 8293, an aberrant member of AFLP cluster 6 (Willems et al., 2001), and strain LMG 11801, separated in AFLP analysis, were closely related to genospecies II (46-59\% hybridization) and to each other (55-57\% hybridization). This group of genospecies (II, X and XI) may also have a somewhat closer relationship with the group of genospecies VII and IX. However, since hybridization values varied between 21 and $58 \%$ (mean $37 \pm 9 \%$ ), with more than half the values below $40 \%$ (see table in IJSEM Online), the significance of this observation is not clear. Although only a limited comparison is possible, it is worth noting that in an analysis of $16 \mathrm{~S}-23 \mathrm{~S}$ rDNA spacer sequences, genospecies II and VII did group close to each other (Willems et al., 2001).

Comparison of our data with the amplified rDNA restriction analysis (ARDRA) grouping reported by Molouba et al. (1999) and Doignon-Bourcier et al. (1999) seemed to indicate that the four groups of related species may also be recognizable from their $16 \mathrm{~S}$ rDNA restriction pattern. Again, strains belonging to genospecies VII, IX, X and II were found in one group, ARDRA group C. Members of genospecies I, III and IV belonged to ARDRA groups B and $\mathrm{E}$, members of genospecies VI and VIII to ARDRA group A, and ARDRA groups D and F corresponded to AFLP clusters 4 and 38, respectively, which could not be assigned to any of the 11 genospecies. The only aberration is strain ORS 336, a non-photosynthetic Aeschynomene isolate, of which the subculture LMG 8298 was shown to belong to ARDRA group C with Bradyrhizobium elkanii (Molouba et al., 1999). Subculture LMG 118001, for which no ARDRA profile was available, was used and found to belong to genospecies VI, distinct from Bradyrhizobium elkanii (genospecies II).

The following strains did not group with any of the above genospecies that they were hybridized with: LMG 10717 (aberrant member of AFLP cluster 33; Willems et al., 2001), LMG 10666 (AFLP cluster 24), LMG 10698 (AFLP cluster 25), LMG 12200 (AFLP cluster 4), LMG 10306 (AFLP cluster 14), LMG 11815 (AFLP cluster 11), LMG 15249 (AFLP cluster 38), LMG 15165 (AFLP cluster 43) and LMG 15422 (AFLP cluster 27). They, and other members of the same AFLP clusters, may represent additional genospecies, but more strains from each of these clusters should be included in DNA-DNA hybridizations to verify this.

Formal proposals to name the new genospecies cannot currently be put forward because differentiating phenotypic data are as yet not available. The bradyrhizobia represent a challenge in this respect because their slow and scanty growth on many standard media hampers the use of standardized techniques such as BIOLOG metabolic profiling or API carbon substrate utilization tests.

\section{Photosynthetic bradyrhizobia}

A number of Bradyrhizobium isolates from Aeschynomene species produce bacteriochlorophyll and are capable of photosynthesis. Whereas a separate genus, 'Photorhizobium' was initially proposed for strain BTAil (Eaglesham et al., 1990), 16S rDNA sequences indicated that this organism unambiguously belongs to the Bradyrhizobium cluster (Young et al., 1991; Wong et al., 1994). It has since been suggested the photosynthetic bradyrhizobia may represent a separate species (So et al., 1994; Fleischman \& Kramer, 1998). In an extensive phenotypic study of Aeschynomene isolates, Ladha \& So (1994) found that these organisms formed a single phenon, clearly distinct from members of Bradyrhizobium, Rhizobium and Azorhizobium. This phenon contained three distinct subgroups A, B and C. Our own data have shown that Aeschynomene isolates belong to at least two different genospecies (VI and VIII). In addition, AFLP clusters 4 and 11, which include photosynthetic strains, have not yet been assigned to any genospecies and at least 11 other photosynthetic Aeschynomene isolates grouped separately in AFLP analysis (Willems et al., 2000). This suggests an even larger diversity among photosynthetic strains. Only two of the strains used in the phenotypic study of Ladha \& So (1994) were included in our study and therefore only a very limited comparison is possible. Strains ORS 322 (= LMG $15403=$ LMG 8073) and BTAil (= LMG 11795) belonged to phenons $6 \mathrm{~B}$ and $6 \mathrm{C}$, respectively, in the study of Ladha \& So (1994) and to genospecies VI and VIII according to our combined DNA-DNA hybridization and AFLP results (Willems et al., 2000).

The somewhat higher relationship between the photosynthetic genospecies VI and VIII $(40 \pm 8 \%)$ may indicate that they do form a separate subgroup among bradyrhizobia. In ARDRA analysis (Molouba et al., 1999; Doignon-Bourcier et al., 1999), both belonged to ARDRA group A. In full-length 16S rDNA sequence analysis, only strains BTAil (= LMG 11795), representing genospecies VIII, and LMG 12187 (Molouba et al., 1999), which grouped separately in AFLP analysis (Willems et al., 2000), were included. They grouped together with the photosynthetic strain USDA 4377 and the misnamed Blastobacter denitrificans (Molouba et al., 1999). No representative of genospecies VI has so far been included in $16 \mathrm{~S}$ rDNA sequence analysis, but from the ARDRA grouping it seems likely that these genospecies will group together. It thus seems that the earlier proposal of Eaglesham et al. (1990) to unite photosynthetic strains in a separate taxon has re-emerged. Genospecies VI and VIII did form a separate entity among bradyrhizobia, although it is not clear whether they should be regarded as a separate photosynthetic genus, especially since our data indicated that other photosynthetic bradyrhizobia do not belong to these genospecies and may be quite different. In defining the taxonomic group that includes genospecies VI and VIII, these other strains should be excluded. To 
complete the evaluation of the taxonomic status of the photosynthetic bradyrhizobia, an additional $16 \mathrm{~S}$ rDNA sequence of a representative of genospecies VI and additional phenotypic data are required.

\section{Comparison of DNA-DNA hybridization and AFLP analysis}

Our results allowed a quite comprehensive comparison of AFLP analysis and DNA-DNA hybridization. The AFLP clusters were delineated at $50 \%$ similarity (Pearson product-moment correlation coefficient, expressed as a percentage), a value chosen by comparison with published data in other groups (Willems et al., 2000), and genospecies (see table in IJSEM Online) were defined as showing at least $60 \%$ internal DNA homology. In Fig. 1, a schematic overview of the AFLP results plus the genospecies illustrates that it is not possible to delineate the genospecies by using a fixed level of AFLP similarity. For example, AFLP clusters of genospecies I grouped at $20 \%$ AFLP similarity, whereas the AFLP clusters that constituted genospecies VII grouped at $42 \%$ AFLP similarity. From our data, it is evident that the boundary of $50 \%$ AFLP similarity defines clusters at an infraspecific level which, within most genospecies, cannot be distinguished by DNA-DNA hybridization (e.g. AFLP clusters 6, 7, 8 and 9 in genospecies VI). On the other hand, some groupings of AFLP clusters inside a genospecies do stand out in the DNA-DNA hybridization data, although this may be quite difficult to judge from an incomplete data matrix. For example, again in genospecies VI, the group of AFLP clusters 6, 7, 8 and 9 could be distinguished from the group of AFLP clusters 2 and 3. From our data, it is concluded that, within Bradyrhizobium, AFLP analysis as applied by us (Willems et al., 2000) is a very fine typing technique that provides information at the infraspecific to strain level.

\section{Concluding remarks}

In this paper, extensive DNA-DNA hybridization data are presented on Bradyrhizobium strains, many of which were previously studied with techniques such as 16S ARDRA (Molouba et al., 1999; DoignonBourcier et al., 1999), AFLP analysis (Willems et al., 2000, 2001) and 16S-23S rDNA spacer (ITS) sequence analysis (Willems et al., 2001). Because of the relatively small 16S rDNA sequence divergence among bradyrhizobia, the 16S ARDRA yielded only seven main groups among these bacteria. AFLP and ITS sequence analyses demonstrated the existence of many more groups. The taxonomic significance and interpretation of these groups, however, remained unclear. Again, because of the relatively high similarity of $16 \mathrm{~S}$ rDNA sequences of bradyrhizobia (So et al., 1994; Molouba et al., 1999), phylogenetic trees on the basis of $16 \mathrm{~S}$ rDNA sequences - apart from clearly showing the separate position of Bradyrhizobium elkanii and related strains from other bradyrhizobia - do not provide much scope to explore the relationships among the many groups of bradyrhizobia. The availability of a microplate method for DNA-DNA hybridization, requiring relatively small amounts of DNA, allows this type of experiment to be used more easily on a larger number of strains. Comparison with the DNA hybridization data now permits 'taxonomic calibration' of different techniques, i.e. establishing the taxonomic level at which their results may provide information inside Bradyrhizobium. As explained above, AFLP may provide infraspecific information. ITS analysis on a subset of strains gave essentially similar groups to those found by AFLP, but groupings deeper in the dendrogram were better resolved (Willems et al., 2001). From comparison of the ITS tree with the DNA hybridization matrix, it is evident that ITS sequence analysis does reveal the different genospecies, as well as infraspecific groups. Furthermore, genospecies which seem to demonstrate a close relationship from DNA-DNA hybridizations (e.g. I, III, IV and V) also group together in the ITS dendrogram (Willems et al., 2001). Relationships at genus level cannot be recognized in the ITS dendrogram: e.g. Nitrobacter and Blastobacter strains group among members of Bradyrhizobium. This last observation clearly depends on the acceptance of current genus delineation in this group. It has been suggested that the taxonomy of these groups needs revision (Young et al., 1991; Wong et al., 1994) and therefore ITS sequences may prove a useful source of additional genotypic information.

So far, ITS sequences are only available for the first seven genospecies. Provided that data become available for all genospecies, ITS analysis may be used to assign an unknown Bradyrhizobium isolate to one of the genospecies. However, unless the new strain clearly belongs to one of the existing ITS types ( $>99 \%$ sequence similarity), DNA-DNA hybridization will still remain necessary to establish its taxonomic place and identity. In that case, the ITS sequence data will provide indications as to which of the species are the closest and thus reduce the number of hybridizations needed. Combined ITS sequence analysis and selected DNA-DNA hybridization may thus provide a useful general strategy for the identification of bradyrhizobia. In addition, ITS sequence analysis may lead to the construction of a large framework in which the various Bradyrhizobium groups and genospecies that have been described by different authors (e.g. Urtz \& Elkan, 1996; Barrera et al., 1997; Lafay \& Burdon, 1998) can be brought together.

\section{ACKNOWLEDGEMENTS}

The authors thank C. Ge, Soil and Fertilizers Institute, Chinese Academy of Agricultural Sciences, for providing Bradyrhizobium liaoningense strains. A.W. and M.G. are grateful to the Fund for Scientific Research, Flanders for a position as Postdoctoral Research Fellow and for research and personnel grants, respectively. J.G. was supported by a grant 'Concerted Research Action 12050797' from 
the 'Ministerie van de Vlaamse Gemeenschap, Bestuur Wetenschappelijk Onderzoek' Belgium. This work was supported by BRG (Office of Genetic Resources, France). F.D. B. is indebted to the French Ministry of Education for a $\mathrm{PhD}$ research grant.

\section{REFERENCES}

Barrera, L. L., Trujillo, M. E., Goodfellow, M., García, F. J., Hernández-Lucas, I., Dávila, G., van Berkum, P. \& MartínezRomero, E. (1997). Biodiversity of bradyrhizobia nodulating Lupinus spp. Int J Syst Bacteriol 47, 1086-1091.

Date, R. A. \& Decker, A. M. (1965). Minimal antigenic constitution of 28 strains of Rhizobium japonicum. Can J Microbiol 11, 1-8.

De Ley, J., Cattoir, H. \& Reynaerts, A. (1970). The quantitative measurement of DNA hybridization from renaturation rates. Eur J Biochem 12, 133-142.

Doignon-Bourcier, F., Sy, A., Willems, A., Torck, U., Dreyfus, B., Gillis, M. \& de Lajudie, P. (1999). Diversity of bradyrhizobia from 27 tropical Leguminosae species native of Senegal. Syst Appl Microbiol 22, 647-661.

Doignon-Bourcier, F., Willems, A., Coopman, R., Laguerre, G., Gillis, M. \& de Lajudie, P. (2000). Genotypic characterization of Bradyrhizobium strains nodulating small Senegalese legumes by 16S-23S rRNA intergenic gene spacers and amplified length polymorphism fingerprint analyses. Appl Environ Microbiol 66, 3987-3997.

Dupuy, N., Willems, A., Pot, B. \& 7 other authors (1994). Phenotypic and genotypic characterization of bradyrhizobia nodulating the leguminous tree Acacia albida. Int $J$ Syst Bacteriol 44, 461-473.

Eaglesham, A. R. J., Ellis, J. M., Evans, W. R., Fleischman, D. E., Hungria, M. \& Hardy, R. W. F. (1990). The first photosynthetic $\mathrm{N}_{2}$-fixing rhizobium: characteristics. In Nitrogen Fixation: Achievements and Objectives, pp. 805-811. Edited by P. M. Gresshoff, L. E. Roth, G. Stacey \& W. L. Newton. New York: Chapman \& Hall.

Ezaki, T., Hashimoto, Y. \& Yabuuchi, E. (1989). Fluorometric deoxyribonucleic acid-deoxyribonucleic acid hybridization in microdilution wells as an alternative to membrane filter hybridization in which radioisotopes are used to determine genetic relatedness among bacterial strains. Int $J$ Syst Bacteriol 39, 224-229.

Fleischman, D. \& Kramer, D. (1998). Photosynthetic rhizobia. Biochim Biophys Acta 1364, 17-36.

Gillis, M., De Ley, J. \& De Cleene, M. (1970). The determination of molecular weight of bacterial genome DNA from renaturation rates. Eur J Biochem 12, 143-153.

Goris, J., Suzuki, K., De Vos, P., Nakase, T. \& Kersters, K. (1998). Evaluation of a microplate DNA-DNA hybridization method compared with the initial renaturation method. Can J Microbiol 44, 1148-1153.

Hollis, A. B., Kloos, W. E. \& Elkan, B. E. (1981). DNA:DNA hybridization studies of Rhizobium japonicum and related Rhizobiaceae. J Gen Microbiol 123, 215-222.

Jordan, D. C. (1982). Transfer of Rhizobium japonicum Buchanan 1980 to Bradyrhizobium japonicum gen. nov., a genus of slowgrowing, root nodule bacteria from leguminous plants. Int $J$ Syst Bacteriol 32, 136-139.

Ladha, J. K. \& So, R. B. (1994). Numerical taxonomy of photosynthetic rhizobia nodulating Aeschynomene species. Int J Syst Bacteriol 44, 62-73.
Lafay, B. \& Burdon, J. J. (1998). Molecular diversity of rhizobia occurring on native shrubby legumes in Southeastern Australia. Appl Environ Microbiol 64, 3989-3997.

Laguerre, G., van Berkum, P., Amarger, N. \& Prévost, D. (1997). Genetic diversity of rhizobial symbionts isolated from legume species within the genera Astragalus, Oxytropis, and Onobrychis. Appl Environ Microbiol 63, 4748-4758.

McConaughy, B. L., Laird, C. D. \& McCarthy, B. J. (1969). Nucleic acid reassociation in formamide. Biochemistry 8, 3289-3295.

Marmur, J. (1961). A procedure for the isolation of deoxyribonucleic acid from micro-organisms. J Mol Biol 3, 208-218.

Molouba, F., Lorquin, J., Willems, A., Hoste, B., Giraud, E., Dreyfus, B., Gillis, M., de Lajudie, P. \& Masson-Boivin, C. (1999). Photosynthetic bradyrhizobia from Aeschynomene spp. are specific to stem-nodulated species and form a separate $16 \mathrm{~S}$ ribosomal DNA restriction fragment length polymorphism group. Appl Environ Microbiol 65, 3084-3094.

So, R. B., Ladha, J. K. \& Young, J. P. W. (1994). Photosynthetic symbionts of Aeschynomene spp. form a cluster with bradyrhizobia on the basis of fatty acid and rRNA analyses. Int $J$ Syst Bacteriol 44, 392-403.

Stackebrandt, E. \& Goebel, B. M. (1994). Taxonomic note: a place for DNA-DNA reassociation and $16 \mathrm{~S}$ rRNA sequence analysis in the present species definition in bacteriology. Int $J$ Syst Bacteriol 44, 846-849.

Sterner, J. P. \& Parker, M. A. (1999). Diversity and relationships of bradyrhizobia from Amphicarpaea bracteata based on partial nod and ribosomal sequences. Syst Appl Microbiol 22, 387-392.

Urtz, B. E. \& Elkan, G. H. (1996). Genetic diversity among Bradyrhizobium isolates that effectively nodulate peanut (Arachis hypogaea). Can J Microbiol 42, 1121-1130.

Vinuesa, P., Rademaker, J. L. W., de Bruijn, F. J. \& Werner, D. (1998). Genotypic characterization of Bradyrhizobium strains nodulating endemic woody legumes of the Canary Islands by PCR-restriction fragment length polymorphism analysis of genes encoding 16S rRNA (16S rDNA) and 16S-23S rDNA intergenic spacers, repetitive extragenic palindromic PCR genomic fingerprinting, and partial $16 \mathrm{~S}$ rDNA sequencing. Appl Environ Microbiol 64, 2096-2104.

Willems, A., Doignon-Bourcier, F., Coopman, R., Hoste, B., de Lajudie, P. \& Gillis, M. (2000). AFLP fingerprint analysis of Bradyrhizobium strains isolated from Faidherbia albida and Aeschynomene species. Syst Appl Microbiol 23, 137-147.

Willems, A., Coopman, R. \& Gillis, M. (2001). Comparison of sequence analysis of $16 \mathrm{~S}-23 \mathrm{~S}$ rDNA spacer regions, AFLP analysis, and DNA-DNA hybridizations in Bradyrhizobium. Int J Syst Evol Microbiol 51, 623-632.

Wong, F. Y. K., Stackebrandt, E., Ladha, J. K., Fleischman, D. E., Date, R. A. \& Fuerst, J. A. (1994). Phylogenetic analysis of Bradyrhizobium japonicum and photosynthetic stem-nodulating bacteria from Aeschynomene species grown in separated geographical regions. Appl Environ Microbiol 60, 940-946.

Young, J. P. W., Downer, H. L. \& Eardley, B. D. (1991). Phylogeny of the phototrophic rhizobium strain BTAil by polymerase chain reaction-based sequencing of a 16S rRNA gene segment. J Bacteriol 173, 2271-2277.

Zhang, X., Nick, G., Kaijalainen, S., Terefework, Z., Paulin, L., Tighe, S. W., Graham, P. H. \& Lindström, K. (1999). Phylogeny and diversity of Bradyrhizobium strains isolated from the root nodules of peanut (Arachis hypogaea) in Sichuan, China. Syst Appl Microbiol 22, 378-386. 